\title{
Biscarboxy-Functionalized Imidazole and Palladium as Highly Active Catalytic System in Protic Solvents: Methanol and Water
}

\author{
Regina Martínez, Isidro M. Pastor,* Miguel Yus* \\ Departamento de Química Orgánica, Facultad de Ciencias and Instituto de Síntesis Orgánica (ISO), Universidad de Alicante, Apdo. 99, \\ 03080 Alicante, Spain \\ Fax: (+34)965903549 \\ E-mail: ipastor@ua.es, yus@ua.es
}

Received: The date will be inserted once the manuscript is accepted.

\begin{abstract}
The coupling reaction between aryl bromides and boron reagents has been efficiently catalyzed by an in situ generated palladium complex obtained from palladium acetate (0.1 mol\%) and 1,3-bis(carboxymethyl)imidazole $\mathbf{1}$ (0.2 mol\%). The catalytic system is very active in protic solvents, especially in $\mathrm{MeOH}$. Biaryl derivatives have been prepared in good isolated yields (up to $>99 \%$ ), and additionally styrene and stilbene derivatives have also been prepared by means of this protocol.
\end{abstract}

Key words: palladium, organometallic reagents, heterocycles, solvent effects, cross-coupling

The chemistry of $N$-heterocyclic carbenes (NHCs) is a field of great current interest, and has witnessed remarkable development in the last two decades. ${ }^{1}$ NHCs have been firmly established as one of the most versatile ligands in the toolkit of the synthetic chemist. The NHC complexes show a variety of interesting applications, including homogeneous catalysis, $^{2}$ antimicrobial, antitumor and cytoxic agents, ${ }^{3}$ and chemistry of materials. ${ }^{4}$ More recently, NHCs have emerged as powerful organic catalysts in molecular chemistry, and in metal-free polymer synthesis. $^{5}$ Imidazolium cations are the most investigated compounds as precursors for NHCs, and the introduction of functionalities into the nitrogen substituents has gradually increased the attention of research. Thus, a variety of functional groups have been attached to modify their physical and chemical properties, including, among others, phosphines, ${ }^{6}$ amines, $^{7}$ alcohols, ${ }^{8}$ esters, ${ }^{9}$ amides, ${ }^{10}$ and sulfonic ${ }^{11}$ and carboxylic acids. 9,12

1,3-Bis(carboxymethyl)imidazole $\mathbf{1}$, which was first observed as a product in the glucose-glycine Maillard reaction, ${ }^{13}$ has been prepared by reaction of glycine, glyoxal, and formaldehyde (Scheme 1). ${ }^{14}$ Also, it can be prepared by the condensation of glyoxal and glycine. $^{15}$ Moreover, the reaction of 1trimethylsilylimidazole with two equivalents of methyl chloroacetate and subsequent ester hydrolysis followed by basic treatment has also allowed the preparation of compound $1 .{ }^{9}$ Imidazole dicarboxylate derivatives have been employed in the preparation of a series of coordination dimers and polymers containing different metal centres, such as lanthanides, ${ }^{16}$ cesium, calcium, strontium, barium, ${ }^{17}$ manganese, ${ }^{18}$ and zinc. ${ }^{19}$ Consequently, in addition to the $\sigma$-donor ability of the NHC ligands, the presence of carboxyl moieties in the imidazolium salt can interact with the corresponding metal centre in the complexation. In fact, the effect of this functional group on the rhodium-catalyzed hydrosilylation of alkenes has been studied by the research group of $\mathrm{Li}$ and Peng. 20

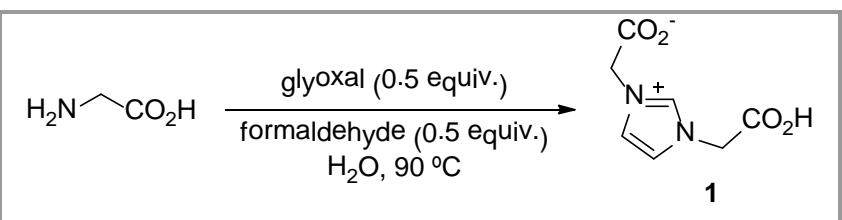

Scheme 1 Synthesis of zwiterionic imidazole $\mathbf{1}$ from glycine.

The synthesis of biaryl compounds in aqueous media from aryl and heteroaryl bromides and chlorides, by means of Suzuki-Miyaura reaction, can be performed at room temperature using the non-ionic vitamin $\mathrm{E}$ based amphiphile polyoxyethanyl $\alpha$-tocopheryl sebacate (PTS) as surfactant, in the presence of different palladium catalysts. $^{21}$ Among them, the NHC-palladium complex [1,3-bis(2,6diisopropylphenyl)imidazol-2-ylidene]chloro[3phenylallyl] palladium(II) have been employed (2 mol\%) in the presence of $\mathrm{Et}_{3} \mathrm{~N}$ as base, with good to excellent results. ${ }^{22}$ Furthermore, palladium catalysts with sulfonate-functionalized-NHC ligands have been prepared and employed for the Suzuki-Miyaura reaction in aqueous phase (i.e. water and i$\mathrm{PrOH} /$ water mixtures). ${ }^{23}$ Çetinkaya and co-workers have described the preparation of water-soluble NHC complexes of PEPPSI type, ${ }^{24}$ having a carboxylfunctionalized pyridine. $^{25}$ More recently, poly(ethylene glycol)-functionalized imidazolium salts have been also employed in the Suzuki reaction in water. $^{26}$ Consequently, it would be interesting to study the suitability of carboxy-functionalized imidazole derivatives in combination with palladium to perform a cross-coupling reaction, such as SuzukiMiyaura reaction. During the last five years, we have been studying different transformations mediated by catalytic systems prepared by hydroxy-functionalized imidazolium derivatives and palladium ${ }^{27}$ or rhodium. ${ }^{28}$ We wish to present herein a study on the catalytic system formed by palladium and bis(carboxymethyl)imidazole $\mathbf{1}$ for the cross-coupling between aryl bromides and boron reagents (i.e. aryl boronic acids and potassium aryltrifluoroborates) in protic solvents, such as water and methanol. 
Initially, we chose the coupling between phenylboronic acid and 4-bromoanisole in the presence of the catalytic system zwitterion $1 / \mathrm{Pd}(\mathrm{OAc})_{2}$ in order to study the optimal reaction conditions. Among the different variables that could have impact on the yield of the biaryl product, we considered the following five parameters. (1) Solvent: Four different solvents were chosen, that is, methanol and water as polar protic solvents, and to compare with, a polar non-protic solvent, e.g. dimethylacetamide (DMA), and a non-polar solvent as toluene. (2) Base: It is known that the base plays an essential role in the Suzuki-Miyaura reaction, ${ }^{29}$ $\mathrm{K}_{2} \mathrm{CO}_{3}$ and $\mathrm{Cs}_{2} \mathrm{CO}_{3}$ being often employed; so, we wanted to test them and also other inorganic bases such as $\mathrm{KHCO}_{3}$ and $\mathrm{K}_{3} \mathrm{PO}_{4}$, and an organic base, such as $\mathrm{Et}_{3} \mathrm{~N}^{30}$ (3) Additive: The presence or absence of an additive was taken into account due to its property of stabilizing active palladium species, ionic surfactants [i.e. tetrabutylammonium bromide (TBAB) and cetyltrimethylammonium bromide (CTAB)] and noninonic surfactants, such as PTS, ${ }^{22,31}$ being included in the study. (4) Amount of palladium: $\mathrm{Pd}(\mathrm{OAc})_{2}$ was tested in three levels, i.e. $0.1,0.2$ and 0.5 mol\%. (5) Palladium/1 ratio: The use of imidazole derivative $\mathbf{1}$ as precursor of carboxyl-functionalized NHC can help to stabilize the active species of palladium, particularly in polar solvents, so we considered to study different $\mathrm{Pd} / \mathbf{1}$ ratios (i.e. 2:1, 1:1, $1: 2$ and 1:5), and additionally, to compare, the ligandless reaction. The next point of our planning was to minimize the set of experiments in order to get the maximum information about which were the critical factors and what was the best combination of variables to maximize the yield of 4-methoxybiphenyl 2. ${ }^{32}$ Thus, a design of experiments (DOE) was used, and the selection of experiments was carried out according to a Taguchi L25 array. Furthermore, we wanted to test conventional heating $\left(110{ }^{\circ} \mathrm{C}, 5 \mathrm{~h}\right.$, pressure tube) versus microwave heating $\left(100^{\circ} \mathrm{C}, 1 \mathrm{~h}\right.$, $80 \mathrm{~W}$ of initial potency, sealed tube), so we carried out the experiments using both heating methods and the obtained results are collected in Table 1.

Table 1 Cross-coupling between 4-bromoanisole and phenylboronic acid: Optimization of parameters ${ }^{\mathrm{a}}$

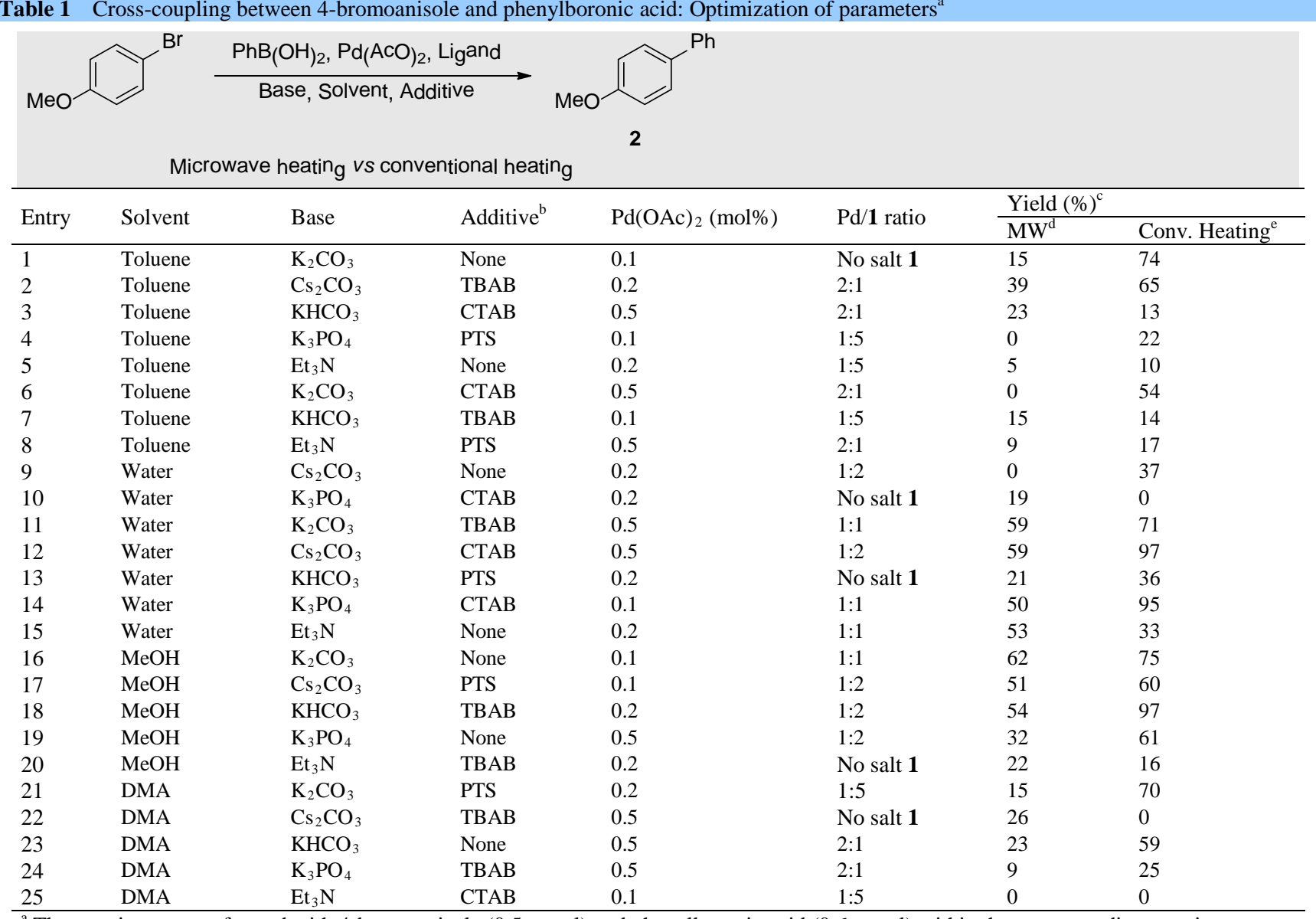

${ }^{\mathrm{a}}$ The reaction was performed with 4-bromoanisole $(0.5 \mathrm{mmol})$ and phenylboronic acid $(0.6 \mathrm{mmol})$ within the corresponding reaction conditions.

${ }^{\mathrm{b}}$ A $20 \mathrm{~mol} \%$ of the corresponding additive was employed.

${ }^{\mathrm{c}}$ The yield was calculated by GLC analysis by employing decane as internal standard.

${ }^{\mathrm{d}}$ Reaction irradiated in a sealed tube at $80 \mathrm{~W}$ of initial power keeping the temperature at $100{ }^{\circ} \mathrm{C}$ for $30 \mathrm{~min}$.

${ }^{\mathrm{e}}$ Reaction heated at $110^{\circ} \mathrm{C}$ for $5 \mathrm{~h}$ in a sealed tube.

The reaction is better performed by conventional heating (Table 1, compare both yield columns and Figure 1a). In agreement with our initial supposition, the presence of carboxylic moieties in the ligand helps in the formation of the catalytic system when performing the reaction in polar protic solvents (such 
as methanol and water), increasing the yield of the reaction (Figure 1b). Albeit, the reaction works under absence of ligand, but the use of the proper amount of compound $\mathbf{1}$ (1:1 and 1:2 palladium/1 ratios) allowed to increase the yields significantly (Figure 1c). Regarding the amount of palladium, there are not noteworthy differences, so $0.1 \mathrm{~mol} \%$ of palladium acetate as the lowest amount was chosen. ${ }^{33}$ Among the bases, carbonates perform better than the rest, and it can be concluded that the organic base $\mathrm{Et}_{3} \mathrm{~N}$ is not the base of choice for this catalytic system, giving low yields independently of the other parameters (Table 1 , entries 5, 8, 15, 20 and 25). ${ }^{33}$ The use of a surfactant as additive or not is still unclear after this set of experiments, although the nature of the surfactant does not give any significant difference. ${ }^{33}$

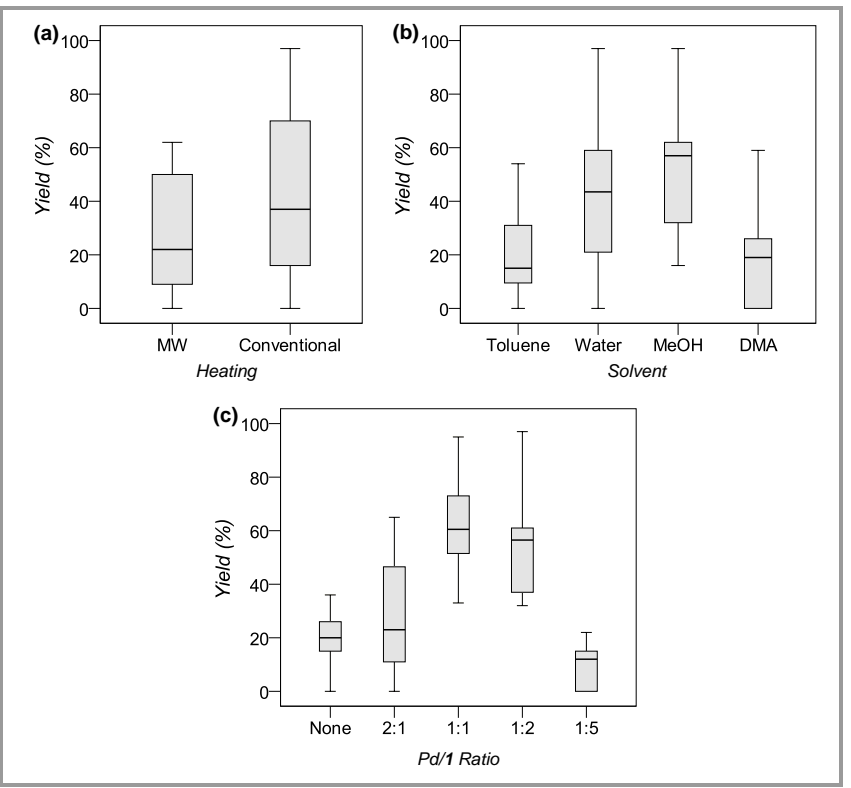

Figure 1 (a) Boxplot of experimental data using microwave irradiation and conventional heating. (b) Boxplot of experimental data employing different solvents. (c) Boxplot of experimental data using different palladium $\mathbf{1}$ ratios.

Taking into consideration the information obtained, we prepared a new set of reactions. Thus, the reactions were performed under conventional heating $\left(110{ }^{\circ} \mathrm{C}\right.$, during $5 \mathrm{~h}$ ) in water or methanol, employing 0.1 mol\% of $\mathrm{Pd}(\mathrm{OAc})_{2}$ in combination with 0.1 or 0.2 mol\% of 1 , in the presence or not of CTAB (20 mol\%) and using either $\mathrm{K}_{2} \mathrm{CO}_{3}$ or $\mathrm{Cs}_{2} \mathrm{CO}_{3}$ as base (Scheme $2)^{33}$ In general, the cross-coupling product 2 was obtained within better yields by carrying out the reaction in methanol, although in water and under some specific reaction conditions (i.e. $\mathrm{Cs}_{2} \mathrm{CO}_{3}$, $\mathrm{CTAB}, \mathrm{Pd} / \mathbf{1}$ ratio $1: 2) 2$ was also obtained in $99 \%$ yield (Scheme 2). Between both bases, cesium carbonate produced statistically better results. ${ }^{33}$ At this point of the analysis, it should be noted that the use of an additive seems to be crucial when performing the reaction in water, whereas it is not in methanol. Actually, both parameters solvent and additive have an important interaction as it is shown in Figure 2. In the absence of additive the reaction works better in methanol; but in the presence of CTAB there is non-significant difference between both, although yields are slightly better in water. Additional data analysis also revealed a minor interaction between the additive and the $\mathrm{Pd} / \mathbf{1}$ ratio parameters, and no-interaction between the solvent and the $\mathrm{Pd} / \mathbf{1}$ ratio.

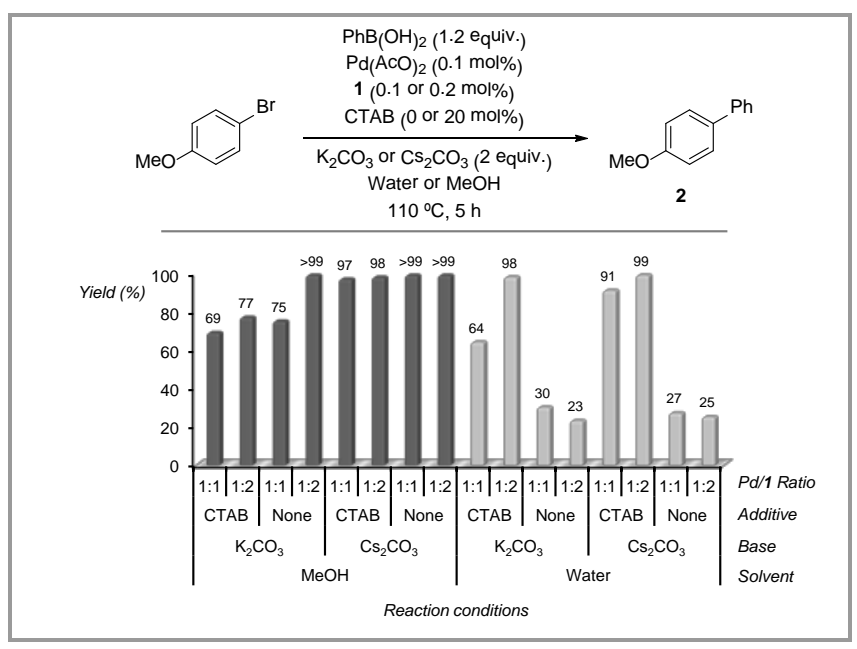

Scheme 2 Cross-coupling reaction between 4-bromoanisole and phenylboronic acid in methanol and water.

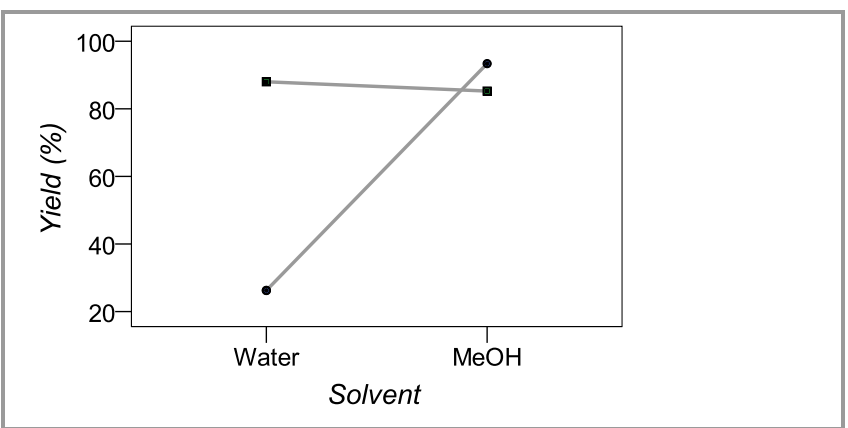

Figure 2 Interaction graph between solvent and the amount of CTAB as additive: (•) 0 mol\%; (•) $20 \mathrm{~mol} \%$.

Accordingly to the results obtained, the use of $\mathrm{Cs}_{2} \mathrm{CO}_{3}$ (2 equiv.), $0.1 \mathrm{~mol} \%$ of $\mathrm{Pd}(\mathrm{OAc})_{2}, 0.2 \mathrm{~mol} \%$ of $\mathbf{1}$, in either methanol or water/CTAB (20 mol\%) are the best reaction conditions for this catalytic system (Table 2). Performing the reaction at room temperature, instead of $110{ }^{\circ} \mathrm{C}$, for $5 \mathrm{~h}$ in $\mathrm{MeOH}$ produced compound 2 in 54\% yield (Table 2, entry 3), albeit the catalytic system was still active and could work until completion of the reaction in $12 \mathrm{~h}$ (Table 2, entry 4). The activity of the catalytic system kept on the same level by reducing the reaction time to 15 minutes even lessening the temperature to $65{ }^{\circ} \mathrm{C}$ (Table 2, entries 5 and 6). The catalytic system in the water/CTAB mixture turned out to be less active. Thus, the reaction at room temperature gave the product in only 15\% yield after 5 h (Table 2, entry 7), and at $110{ }^{\circ} \mathrm{C}$ after 15 minutes just 40\% (Table 2, entry 8) of the product was formed.

In many cases, organotrifluoroborates are demonstrably superior to other organoboron reagents 
in terms of their cross-coupling capabilities, ${ }^{34}$ so the study was extended to the trifluoroborate analogous. The reaction of 4-bromoanisole with potassium phenyltrifluoroborate in the water/CTAB mixture under the optimized reaction conditions, produced after $5 \mathrm{~h}$ the expected biaryl but in just 44\% yield (Table 2, entry 9). This result can be explained by the fact that organotrifluoroborates undergo a hydrolytic equilibrium with the corresponding boronic acid that can affect in the rate of the reaction. ${ }^{35}$ Interestingly, the activity of the catalytic system in methanol resulted to be slightly higher (Table 2, compare entry
3 with entry 10, and entry 6 with entries 11 and 12). Hence, the final product $\mathbf{2}$ was obtained quantitatively in only 5 minutes using $\mathrm{PhBF}_{3} \mathrm{~K}$, instead of the boronic acid. At this point, the optimization study resulted in a very active catalytic system using 1:2 $\mathrm{Pd} / \mathbf{1}$ ratio (at a level $0.1 \mathrm{~mol} \%$ of palladium) employing both boronic acid and trifluoroborate derivatives, with an enhancement of the activity provided by the imidazole derivative $\mathbf{1}^{36,37}$ Furthermore, the use of this catalytic system under the optimal conditions did not produce the homocoupling product.

Table 2 Cross-coupling of organoboron reagents with 4-bromoanisole in $\mathrm{MeOH}$ and $\mathrm{H}_{2} \mathrm{O} / \mathrm{CTAB}^{\mathrm{a}}$

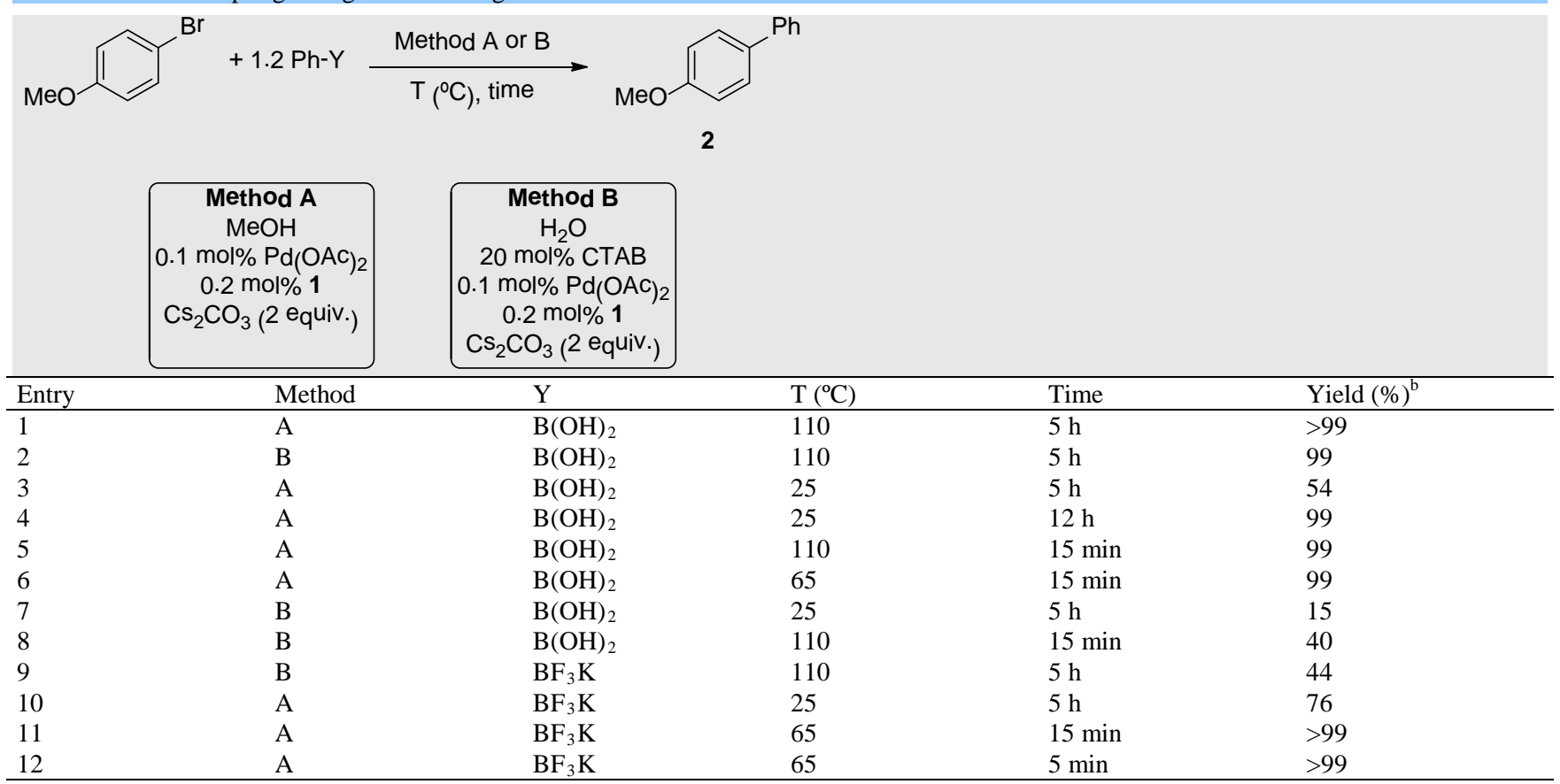

${ }^{a}$ Reaction performed with 4-bromoanisole $(0.5 \mathrm{mmol})$ and phenylboron reagent $(0.6 \mathrm{mmol})$ within the corresponding reaction conditions described as method A or method B.

${ }^{\mathrm{b}}$ The yield was calculated by GLC analysis by employing decane as internal standard.

To further investigate the scope of this catalytic system in the reaction a set of different aryl bromides was cross-coupled with phenylboronic acid and 4methylphenylboronic acid using the optimized conditions, and in order to compare with, the corresponding analogous potassium aryltrifluoroborates were also employed. The results of the biaryl formation are presented in Table 3 . The reaction employing potassium aryltrifluoroborates as coupling partners worked better than the corresponding boronic acids, expect in the case of 4bromophenol and 3-bromopyridine (Table 3, entries 710). The probable deactivation of the catalyst by substrate coordination can explain the lower reactivity for these two bromo derivatives, although the catalyst was not completely deactivated and biaryls $\mathbf{5}$ and $\mathbf{6}$ were obtained with yields ranging from 71 to $90 \%$ by lengthening the reaction time to $5 \mathrm{~h}$ (Table 3 , entries $7-10$, footnote c). The coupling reaction between the more congested 2-bromotoluene with 4methylphenylboronic acid or potassium 4methylphenyltrifluoroborate produced the expected biaryl 10 with similar yields to those obtained for other substitued biaryls such as $\mathbf{9}$ (Table 3, compare entries 15 to 18), proving that there is not influence of the substituent in ortho-position during the catalytic cycle.

The use of other commercially available aromatic organoboron reagents, such as $2-\mathrm{MeC}_{6} \mathrm{H}_{4} \mathrm{BF}_{3} \mathrm{~K}$, 4$\mathrm{F}_{3} \mathrm{CC}_{6} \mathrm{H}_{4} \mathrm{BF}_{3} \mathrm{~K}$, 4- $\mathrm{HOC}_{6} \mathrm{H}_{4} \mathrm{~B}(\mathrm{OH})_{2}$, and 4-t$\mathrm{BuC}_{6} \mathrm{H}_{4} \mathrm{~B}(\mathrm{OH})_{2}$ allowed the preparation of biaryl products 11-17 within reasonably yields (Table 4$)$. The sterically hindered 2-methylphenyl borate derivative was successfully coupled with aryl bromides having electron-donating and electron-withdrawing groups in their structures (Table 4, entries 1 to 3). Additionally, 4-(trifluoromethyl)phenyltrifluoroborate was coupled with 2-bromotoluene producing the expected biaryl 14 in $89 \%$ yield (Table 4, entry 4). Alternatively, 4bromophenyl methyl ketone was successfully reacted under the standard conditions with boronic acids bearing electron-donating groups, such as t-butyl and hydroxy, being products $\mathbf{1 5}$ and $\mathbf{1 6}$ isolated with 99 and $60 \%$ yield. In the latter, the reaction did not 
continue after 15 min (Table 4, entry 6, footnote c). Due to the good results obtained with a heteroaryl derivative together with a boronic acid, 3bromopyridine was coupled with 4- $(t-$ butyl)phenylboronic acid giving the expected biaryl 17 in 90\% after $5 \mathrm{~h}$ (Table 4, entry 7, footnote c). Finally, we were pleased to prove that vinyl boron reagents are suitable reagents for the catalytic system studied. Thus, styrylboronic acid gave the corresponding stilbene derivatives $\mathbf{1 8}$ and $\mathbf{1 9}$ in its reaction, in moderate to good yields, with two different aryl bromides (Table 4, entries 8 and 9). On the contrary, the coupling reaction of potassium vinyltrifluoroborate with 4-bromophenyl methyl ketone under the optimized conditions produced the 4vinylphenyl methyl ketone in lower yield (36\%). The yield of 4-vinylphenyl methyl ketone could not be improved by extending the reaction time to $5 \mathrm{~h}$, neither by adding more equivalents (up to 3 ) of the borate (38\% yield in both experiments).

Table 3 Arylboronic acids versus potassium aryltrifluoroborates in cross-coupling with aryl bromides catalyzed by $\mathrm{Pd} / \mathbf{1}^{\mathrm{a}}$

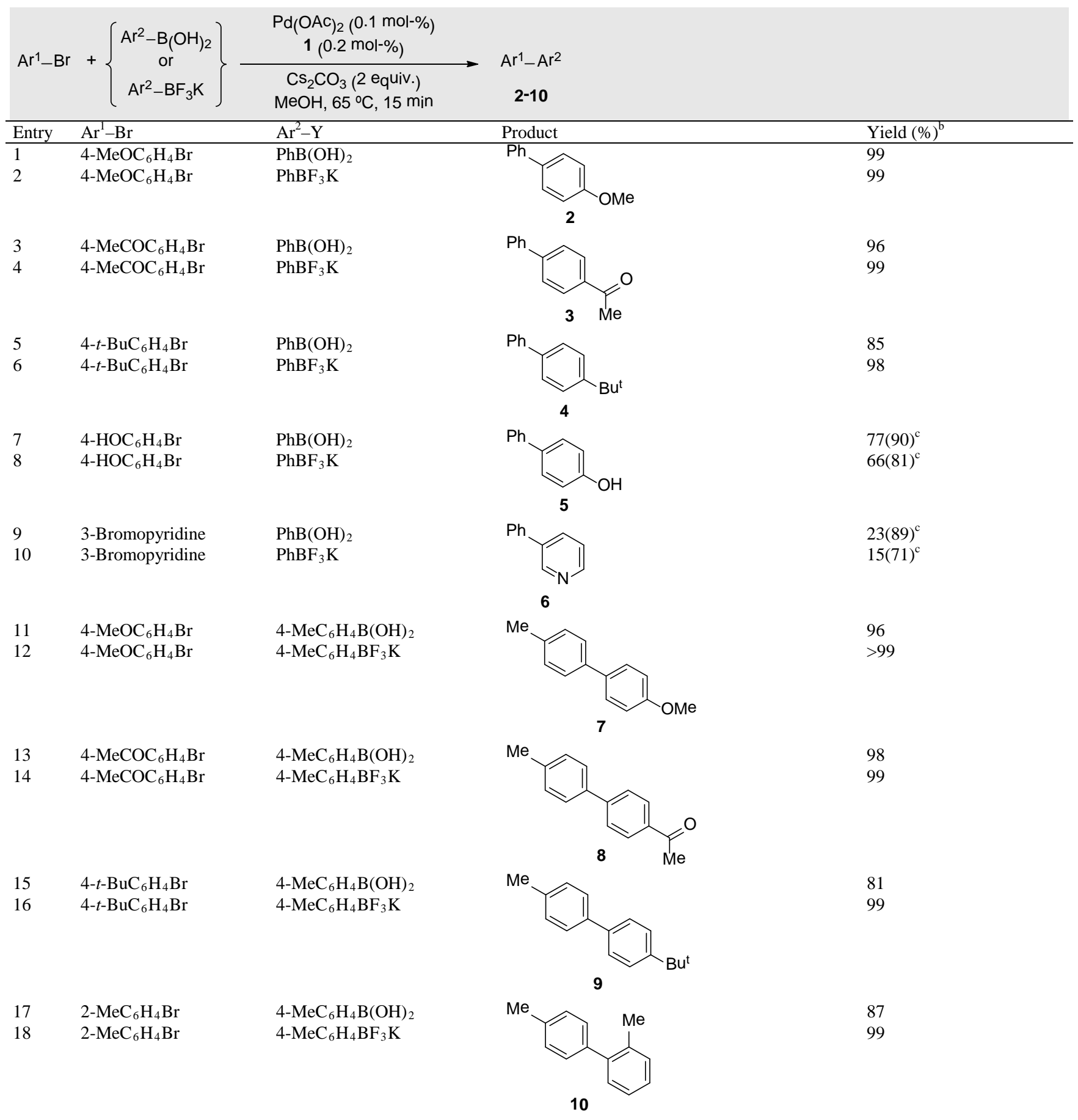

\footnotetext{
${ }^{\mathrm{a}}$ The reaction was performed with aryl bromide (2 mmol), arylboronic acid or potassium aryltrifluoroborate (2.4 mmol), cesium carbonate (4 mmol), palladium acetate (0.002 mmol), 1 (0.004 mmol), $\mathrm{MeOH} \mathrm{(2} \mathrm{mL),} 65^{\circ} \mathrm{C}, 15 \mathrm{~min}$.

${ }^{\mathrm{b}}$ Isolated yield of pure product after purification by flash chromatrography (silica gel; hexane/ethyl acetate mixtures), or recrystallization.

${ }^{\mathrm{c}}$ In brackets, yield after $5 \mathrm{~h}$.
} 
Table 4 Reaction of organoboron reagents with aryl bromides ${ }^{a}$

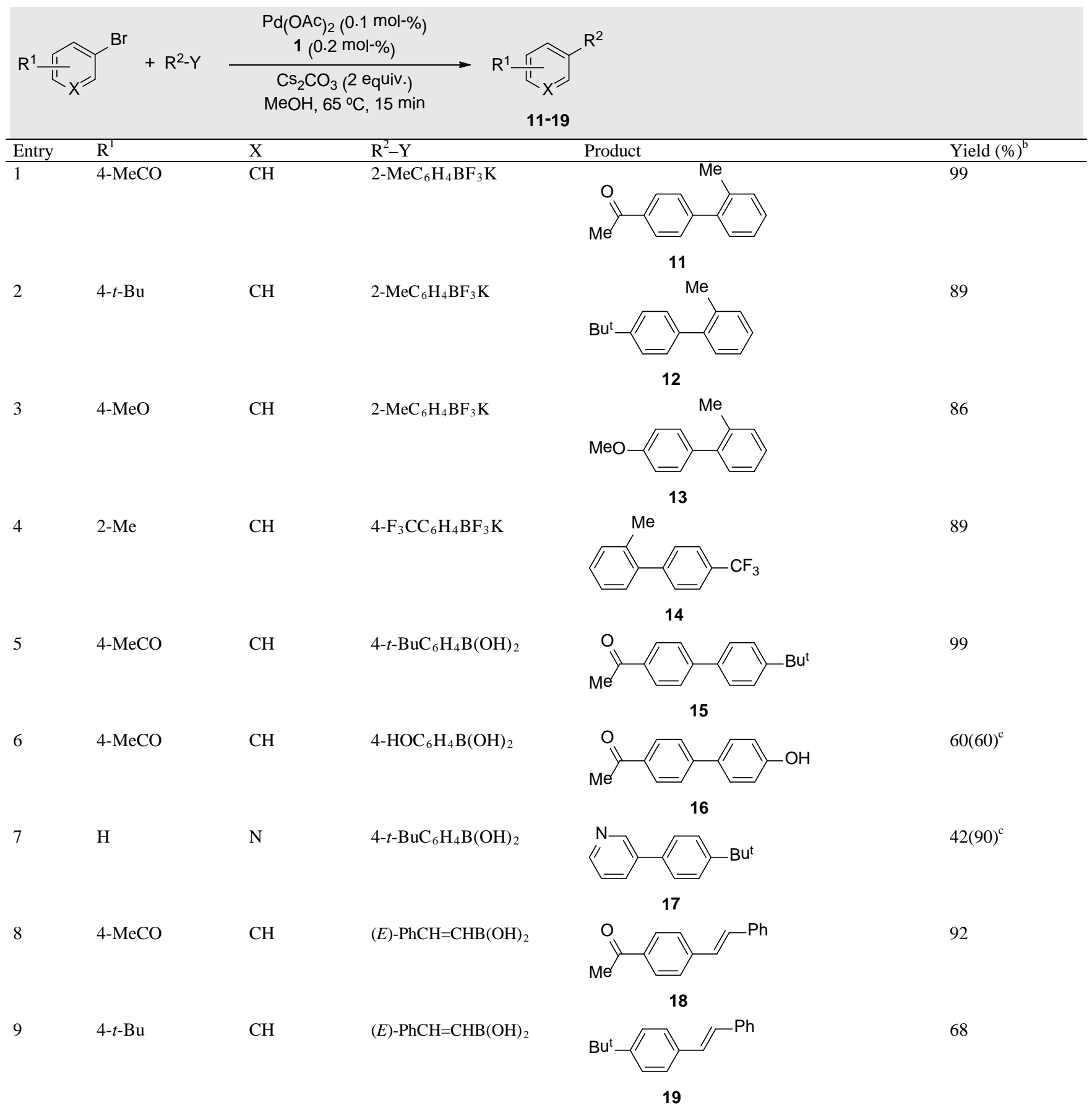

\footnotetext{
mmol), 1 (0.004 mmol), $\mathrm{MeOH}(2 \mathrm{~mL}), 65^{\circ} \mathrm{C}, 15 \mathrm{~min}$.

${ }^{\mathrm{c}}$ In brackets, yield after $5 \mathrm{~h}$.

Mercury forms an amalgam with the catalytically active nanoparticles and if the catalytic reaction stops after the mercury is added the reaction mechanism follows a heterogeneous pathway. It follows a homogeneous pathway if mercury does not suppress the catalytic activity. ${ }^{38}$ Thus, in a representative experiment by using the mixture $\mathrm{Pd}(\mathrm{OAc})_{2} / \mathbf{1}$ under the standard conditions, 4-bromoanisole was reacted with potassium phenyltrifluoroborate, and a large excess of elemental mercury (in a molar ratio of 800 equiv. to the palladium) was added after $1 \mathrm{~min}(20 \%$
}

${ }^{\mathrm{a}}$ The reaction was performed with aryl bromide $(2 \mathrm{mmol})$, boron reagent $(2.4 \mathrm{mmol})$, cesium carbonate $(4 \mathrm{mmol})$, palladium acetate $(0.002$

${ }^{\mathrm{b}}$ Isolated yield of pure product after purification by flash chromatrography (silica gel; hexane/ethyl acetate mixtures), or recrystallization.

yield by GLC analysis using decane as internal standard). This addition did not stall completely the catalytic activity, and the yield of $65 \%$ was determined after 15 minutes. In contrast, a parallel mercury-free reaction reached quantitative yield over the same period. Consequently, it seems to be a homogeneous palladium catalyst operating after the addition of mercury, albeit the formation of few amounts of nanoparticles (heterogeneous catalyst) cannot be completely ruled out due to the higher 
conversion in the absence of mercury (control experiment).

To conclude, we have reported an efficient protocol for the cross-coupling between aryl bromides and boronic acids or trifluoroborates by using 1,3bis(carboxymethyl)imidazolyl-palladium catalyst formed in situ from palladium(II) acetate and the imidazole 1. The optimization process (via a Design of Experiments) allowed us to find that with this type of carboxy-functionalized imidazole the reaction proceeded better in polar protic solvents, such as $\mathrm{MeOH}$ and water, under conventional heating (vs. microwave heating). Additionally, the use of a double amount of imidazole $\mathbf{1}$ to palladium proved to be the best ratio. The information derived from our study also showed an interaction between three of the considered factors: solvent, the use of an additive and palladium $\mathbf{1}$ ratio. Moreover, the catalytic system (with a level of $0.1 \mathrm{~mol} \%$ ) in $\mathrm{MeOH}$ proved to be very active giving the coupling products from a variety of aryl bromides and aryl- and vinylboron reagents (i.e. boronic acids and trifluoroborates) in 15 minutes. In general, potassium aryltrifluorborates gave better results than the boronic acids, except in the case of hydroxyaryl or heteroaryl bromides.

All commercially available reagents (Acros, Aldrich, Fluka) were used without further purification. Melting points were determined with a Reichert Thermovar hot plate apparatus and are uncorrected. NMR spectra were recorded on a Bruker-Avance 300 and a BrukerAvance 400 (300 and $400 \mathrm{MHz}$ for ${ }^{1} \mathrm{H}-\mathrm{NMR}$ and 75 and $100 \mathrm{MHz}$ for ${ }^{13} \mathrm{C}-\mathrm{NMR}$ ) using, except otherwise stated, $\mathrm{CDCl}_{3}$ as solvent and TMS as internal standard; chemical shifts are given in $\delta$ (ppm) and coupling constants $(J)$ in Hertz. Mass spectra (EI) were obtained at $70 \mathrm{eV}$ on an Agilent 5973 spectrometer, fragment ions in $\mathrm{m} / \mathrm{z}$ with relative intensities (\%) in parenthesis. Infrared spectra were recorded on a Perkin-Elmer Spectrum 100 spectrometer as neat solids. Analytical TLC was performed on Merck aluminum sheets with silica gel 60 F254. Silica gel P/UV254 with $\mathrm{CaSO}_{4}$ was employed for preparative thin layer chromatography. Microwave reactions were performed with a CEM Discover Synthesis Unit (CEM Corp., Matthews, NC) with a continuous focused microwave power delivery system in glass vessels $(10 \mathrm{~mL})$ sealed with a septum under magnetic stirring.

\section{1,3-Bis(carboxymethyl)imidazole (1) $)^{9,14}$}

Glyoxal trimer dihydrate (0.35 g, $5 \mathrm{mmol}$ of glyoxal), paraformaldehyde (0.16 g, $5 \mathrm{mmol})$ and glycine $(0.75$ $\mathrm{g}, 10 \mathrm{mmol}$ ) were added to a round-bottom flask. Then $7 \mathrm{~mL}$ of water were added and the resulting mixture was heated at $95{ }^{\circ} \mathrm{C}$ during $2 \mathrm{~h}$. The water was removed under reduced pressure, and the crude was washed with a small amount of water. Recrystallization of the solid residue in methanol twice furnished the imidazolium salt $\mathbf{1}$.

White solid; yield: 0.6 g (65 \%); m.p. $=308{ }^{\circ} \mathrm{C}$ decomp. (MeOH/ $\mathrm{H}_{2} \mathrm{O}$; lit.: $290{ }^{\circ} \mathrm{C}$ decomp.).

${ }^{1} \mathrm{H}$ NMR (300 MHz, $\mathrm{D}_{2} \mathrm{O}$ ): $\delta=5.00$ (s, $2 \times \mathrm{CH}_{2}, 2 \mathrm{H}$ ), 7.51 (s, NCHCHN, 2H), 8.85 (s, NCHN, 1H).

${ }^{13} \mathrm{C}$ NMR (75 MHz, $\left.\mathrm{D}_{2} \mathrm{O}\right): \delta=52.6,124.8,139.2$, 172.6 .

\section{Cross-coupling or Aryl Halides with Organoboron Reagents. Typical Procedure}

In a vessel, the aryl bromide ( $2 \mathrm{mmol}$ ) and the boronic acid $(2.4 \mathrm{mmol})$ or the trifluoroborate $(2.4 \mathrm{mmol})$ were added to a solution of $\mathrm{Pd}(\mathrm{OAc})_{2}(0.4 \mathrm{mg}, 0.002$ mmol), imidazole 1 (0.8 $\mathrm{mg}, 0.004 \mathrm{mmol})$, and cesium carbonate $(1.3 \mathrm{~g}, 4 \mathrm{mmol})$, in $\mathrm{MeOH}(2 \mathrm{~mL}$, method A) or $\mathrm{H}_{2} \mathrm{O}$ (2 mL, method B) with CTAB (0.15 g, $0.4 \mathrm{mmol})$. The resulting mixture was refluxed with stirring for $15 \mathrm{~min}$ (or $5 \mathrm{~h}$ ) and, after allowing the reaction to cool down to room temperature, it was extracted with ethyl acetate $(5 \times 5$ $\mathrm{mL})$. The combined organic layers were filtered through a pad of Celite, and then the solvent was eliminated under reduced pressure. The crude products were purified by recrystallization in $\mathrm{MeOH} / \mathrm{H}_{2} \mathrm{O}$, or by preparative TLC (silica gel with ethyl acetate/hexane mixtures). Yields are given in Tables 3 and 4. Physical, spectroscopic, and analytical data, as well as literature references of known compounds follow.

\section{4-Methoxybiphenyl (2) ${ }^{39}$}

White solid; yield: $365 \mathrm{mg}$ (99 \%); m.p. = 91-92 ${ }^{\circ} \mathrm{C}$ $\left(\mathrm{MeOH} / \mathrm{H}_{2} \mathrm{O}\right)$ (lit.: $\left.{ }^{39 b} 90-91^{\circ} \mathrm{C}\right)$.

${ }^{1} \mathrm{H}$ NMR (300 MHz, $\mathrm{CDCl}_{3}$ ): $\delta=3.85\left(\mathrm{~s}, \mathrm{OCH}_{3}, 3 \mathrm{H}\right)$, 6.98, 7.30, 7.42, 7.55 (4m, 9×ArH, 2H, 1H, 2H, 4H).

${ }^{13} \mathrm{C} \mathrm{NMR}\left(75 \mathrm{MHz}, \mathrm{CDCl}_{3}\right): \delta=55.3,114.2,126.6$, $126.7,128.1,128.7,133.8,140.8,159.1$.

MS (EI): $m / z=184\left(M^{+}, 100 \%\right), 169$ (45), 141 (38), 115 (25).

\section{4-Phenylacetophenone (3)}

White solid; yield: $387 \mathrm{mg}$ (99 \%); m.p. $=122-123{ }^{\circ} \mathrm{C}$ (MeOH/ $\mathrm{H}_{2} \mathrm{O}$ ) (lit.: ${ }^{40 \mathrm{~b}} 116-118^{\circ} \mathrm{C}$ ).

${ }^{1} \mathrm{H}$ NMR (300 MHz, $\left.\mathrm{CDCl}_{3}\right): \delta=2.64\left(\mathrm{~s}, \mathrm{COCH}_{3}\right.$, $3 \mathrm{H}), 7.38-7.50,7.63,7.69,8.03$ (4m, $9 \times \mathrm{ArH}, 3 \mathrm{H}, 2 \mathrm{H}$, $2 \mathrm{H}, 2 \mathrm{H})$.

${ }^{13} \mathrm{C}$ NMR (75 MHz, $\left.\mathrm{CDCl}_{3}\right): \delta=26.6,127.2,127.3$, 128.1, 128.8, 128.9, 135.8, 139.9, 145.8, 197.2.

MS (EI): $m / z=196\left(M^{+}, 54 \%\right), 181$ (100), 153 (32), 152 (48).

\section{4-(tert-Butyl)biphenyl (4)}

White solid; yield: $410 \mathrm{mg}$ (98\%); m.p. $=52-53{ }^{\circ} \mathrm{C}$ (EtOAc) (lit.: ${ }^{41} 51-52{ }^{\circ} \mathrm{C}$ ). 
${ }^{1} \mathrm{H}$ NMR (300 MHz, $\left.\mathrm{CDCl}_{3}\right): \delta=1.36\left[\mathrm{~s}, \mathrm{C}\left(\mathrm{CH}_{3}\right)_{3}\right.$, 9H], 7.32, 7.40-7.48, 7.52-7.55, 7.58-7.60 (4m, $9 \times \mathrm{ArH}, 1 \mathrm{H}, 4 \mathrm{H}, 2 \mathrm{H}, 2 \mathrm{H})$.

${ }^{13} \mathrm{C}$ NMR (75 MHz, $\mathrm{CDCl}_{3}$ ): $\delta=31.4$, 34.5, 125.7, 126.8, 126.9, 127.0, 128.7, 138.3, 141.0, 150.2.

MS (EI): $m / z=210\left(\mathrm{M}^{+}, 60 \%\right), 196$ (28), 195 (100), 167 (42).

\section{4-Phenylphenol (5) ${ }^{40 \mathrm{~b}}$}

White solid; yield: $265 \mathrm{mg}$ (77 \%); m.p. $=167-168^{\circ} \mathrm{C}$ ( $\mathrm{MeOH} / \mathrm{H}_{2} \mathrm{O}$ ) (lit.: $\left.{ }^{40 \mathrm{~b}} 165-167^{\circ} \mathrm{C}\right)$.

${ }^{1} \mathrm{H}$ NMR (400 MHz, $\mathrm{CDCl}_{3}$ ): $\delta=1.25$ (br s, OH, 1H), 6.91, 7.30, 7.41, 7.48, $7.54(5 \mathrm{~m}, 9 \times \mathrm{ArH}, 2 \mathrm{H}, 1 \mathrm{H}, 2 \mathrm{H}$, 2H, 2H).

${ }^{13} \mathrm{C}$ NMR (100 MHz, $\left.\mathrm{CDCl}_{3}\right): \delta=115.6,128.4$, 128.7, 134.0, 140.7, 155.1.

MS (EI): $m / z=170$ ( $\left.\mathrm{M}^{+}, 100 \%\right), 141$ (18), 115 (13).

3-Phenylpyridine (6) ${ }^{40 a}$

Yellow oil; yield: 73 g (23 \%).

${ }^{1} \mathrm{H}$ NMR (300 MHz, $\left.\mathrm{CDCl}_{3}\right): \delta=7.34-7.43,7.45-$ 7.51, 7.56-7.60 (3m, 6×ArH, 2H, 2H, 2H), 7.87 (ddd, $J=1.7,2.4,7.9 \mathrm{~Hz}, \mathrm{ArH}, 1 \mathrm{H}), 8.59$ (dd, $J=1.7,4.8$ Hz, ArH, 1H), 8.85 (dd, $J=0.7,2.3$ Hz, ArH, 1H).

${ }^{13} \mathrm{C}$ NMR (75 MHz, $\left.\mathrm{CDCl}_{3}\right): \delta=123.4,127.1,128.0$, 129.0, 134.3, 136.6, 137.8, 148.2 y 148.4 .

MS (EI): $m / z=155\left(\mathrm{M}^{+}, 100 \%\right), 154$ (82), 128 (18), 127 (25), 102 (17).

\section{4-Methoxy-4'-methylbiphenyl (7) ${ }^{42}$}

White solid; yield: $390 \mathrm{mg}$ (99 \%); m.p. $=108-109{ }^{\circ} \mathrm{C}$ (EtOAc) (lit.: $\left.{ }^{42} 109-110^{\circ} \mathrm{C}\right)$.

${ }^{1} \mathrm{H}$ NMR (300 MHz, $\mathrm{CDCl}_{3}$ ): $\delta=2.38\left(\mathrm{~s}, \mathrm{CH}_{3}, 3 \mathrm{H}\right)$, 3.85 (s, $\left.\mathrm{OCH}_{3}, 3 \mathrm{H}\right), 6.96(\mathrm{~m}, 2 \times \mathrm{ArH}, 2 \mathrm{H}), 7.22$ (d, $J$ $=7.9 \mathrm{~Hz}, 2 \times \mathrm{ArH}, 2 \mathrm{H}), 7.45,7.51(2 \mathrm{~m}, 4 \times \mathrm{ArH}, 2 \mathrm{H}$, 2H).

${ }^{13} \mathrm{C}$ NMR (75 MHz, $\left.\mathrm{CDCl}_{3}\right): \delta=21.0,55.3,114.1$, 126.6, 127.9, 129.4, 133.7, 136.3, 137.9, 158.9 .

MS (EI): $m / z=198\left(\mathrm{M}^{+}, 100 \%\right), 183$ (51), 155 (26).

1-(4'-methyl-1,1'-biphenyl-4-yl)ethanone (8) ${ }^{43}$

Colourless oil; yield: 417 mg (99\%).

${ }^{1} \mathrm{H}$ NMR (300 MHz, $\mathrm{CDCl}_{3}$ ): $\delta=2.41$ (s, $\left.\mathrm{CH}_{3}, 3 \mathrm{H}\right)$, 2.63 (s, $\left.\mathrm{CH}_{3} \mathrm{CO}, 3 \mathrm{H}\right), 7.28,7.53,7.67,8.02$ (4m, $8 \times \mathrm{ArH}, 2 \mathrm{H}, 2 \mathrm{H}, 2 \mathrm{H}, 2 \mathrm{H})$.

${ }^{13} \mathrm{C} \mathrm{NMR}\left(75 \mathrm{MHz}, \mathrm{CDCl}_{3}\right): \delta=21.2,26.6,126.9$, 127.1, 128.9, 129.7, 135.6, 137.0, 138.2, 145.7, 197.5 .

MS (EI): $m / z=210\left(\mathrm{M}^{+}, 51 \%\right), 196$ (15), 195 (100), 165 (24), 152 (31).

\section{4-(tert-Butyl)-4'-methylbiphenyl (9) ${ }^{44}$}

White solid; yield: $445 \mathrm{mg}$ (99\%); m.p. $=75-76{ }^{\circ} \mathrm{C}$ (EtOAc) (lit.: ${ }^{44} 75-76^{\circ} \mathrm{C}$ ).

${ }^{1} \mathrm{H}$ NMR (300 MHz, $\left.\mathrm{CDCl}_{3}\right): \delta=1.36\left[\mathrm{~s}, \mathrm{C}\left(\mathrm{CH}_{3}\right)_{3}\right.$, 9H], 2.38 (s, $\left.\mathrm{CH}_{3}, 3 \mathrm{H}\right), 7.23$ (d, $J=7.8 \mathrm{~Hz}, 2 \times \mathrm{ArH}$, 2H), 7.43-7.47, 7.50-7.53 (2m, 6×ArH, 3H, 3H).
${ }^{13} \mathrm{C}$ NMR (75 MHz, $\mathrm{CDCl}_{3}$ ): $\delta=21.1,31.4,34.5$, 125.6, 126.6, 126.8, 129.4, 136.7, 138.1, 138.2, 149.9. MS (EI): $m / z=224\left(\mathrm{M}^{+}, 64 \%\right), 210$ (30), 209 (100), 181 (28), 165 (19), 90 (12).

\section{2,4'-Dimethylbiphenyl (10) ${ }^{45}$}

Yellow oil; yield: 360 mg (99\%).

${ }^{1} \mathrm{H} \mathrm{NMR} \mathrm{(300} \mathrm{MHz,} \mathrm{CDCl}_{3}$ ): $\delta=2.28,2.40$ (2s, $\left.2 \times \mathrm{CH}_{3}, 3 \mathrm{H}, 3 \mathrm{H}\right), 7.22-7.25$ (m, $\left.8 \times \mathrm{ArH}, 8 \mathrm{H}\right)$.

${ }^{13} \mathrm{C}$ NMR (75 MHz, $\left.\mathrm{CDCl}_{3}\right): \delta=20.5,21.2,125.7$, 127.0, 128.7, 129.0, 129.8, 130.2, 135.4, 136.4, 139.0, 141.9 .

MS (EI): $m / z=182\left(\mathrm{M}^{+}, 92 \%\right), 181$ (24), 168 (14), 167 (100), 166 (26), 165 (53), 152 (19).

1-(2'-Methyl-1,1'-biphenyl-4-yl)ethanone (11)

Colourless oil; yield: $416 \mathrm{mg}$ (99\%).

${ }^{1} \mathrm{H}$ NMR (300 MHz, $\mathrm{CDCl}_{3}$ ): $\delta=2.27$ (s, $\left.\mathrm{CH}_{3}, 3 \mathrm{H}\right)$, 2.64 (s, $\left.\mathrm{COCH}_{3}, 3 \mathrm{H}\right), 7.20-7.29,4.42,8.01$ (3m, $8 \times \mathrm{ArH}, 4 \mathrm{H}, 2 \mathrm{H}, 2 \mathrm{H})$.

${ }^{13} \mathrm{C} \mathrm{NMR}\left(75 \mathrm{MHz} \mathrm{CDCl}_{3}\right): \delta=20.3,26.6,125.9$, 127.8, 128.2, 129.4, 129.5, 130.5, 135.1, 135.5, 140.7, 146.9, 197.8.

MS (EI): $\mathrm{m} / \mathrm{z}=211\left(\mathrm{M}^{+}+1,9 \%\right), 210\left(\mathrm{M}^{+}, 52\right), 196$ (16), 195 (100), 165 (34), 167 (11), 166 (11), 152 (28).

\section{4'-(tert-Butyl)-2-methyl-1,1'-biphenyl (12) ${ }^{47}$}

Colourless solid; yield: $400 \mathrm{mg}$ (89 \%); m.p. = 39-40 ${ }^{\circ} \mathrm{C}$ (EtOAc) (lit.: $\left.{ }^{47} 40-41^{\circ} \mathrm{C}\right)$.

${ }^{1} \mathrm{H}$ NMR (300 MHz, $\left.\mathrm{CDCl}_{3}\right): \delta=1.36\left(\mathrm{~s}, \mathrm{CH}_{3}, 3 \mathrm{H}\right)$, $2.28\left[\mathrm{C}\left(\mathrm{CH}_{3}\right)_{3}, 9 \mathrm{H}, \mathrm{s}\right], 7.21-7.26,7.42(2 \mathrm{~m}, 8 \times \mathrm{ArH}$, $6 \mathrm{H}, 2 \mathrm{H})$.

${ }^{13} \mathrm{C}$ NMR (75 MHz, $\mathrm{CDCl}_{3}$ ): $\delta=20.6,31.4,34.5$, $124.9,125.7,127.0,128.8,129.9,130.3,135.4,138.9$, $141.8,149.5$.

MS (EI): $m / z=224\left(M^{+}, 37 \%\right), 210$ (18), 209 (100), 181 (12), 165 (15).

\section{4'-Methoxy-2-methyl-1,1'-biphenyl (13) ${ }^{48}$}

Colourless solid; yield: $341 \mathrm{mg}$ (86 \%); m.p. = 50-52 ${ }^{\circ} \mathrm{C}$ (EtOAc) (lit.: $\left.{ }^{48} 51-52{ }^{\circ} \mathrm{C}\right)$.

${ }^{1} \mathrm{H}$ NMR (300 MHz, $\left.\mathrm{CDCl}_{3}\right): \delta=2.27\left(\mathrm{~s}, \mathrm{CH}_{3}, 3 \mathrm{H}\right)$, $3.83\left(\mathrm{~s}, \mathrm{OCH}_{3}, 3 \mathrm{H}\right), 6.94,7.21-7.25$ (2m, 8×ArH, 2H, $6 \mathrm{H})$.

${ }^{13} \mathrm{C}$ NMR (75 $\left.\mathrm{MHz}, \mathrm{CDCl}_{3}\right): \delta=20.5,55.2,113.4$, $125.7,126.9,129.9,130.2,130.3,134.3,135.4,141.5$, 158.5 .

MS (EI): $m / z=198\left(\mathrm{M}^{+}, 100 \%\right), 183$ (27), 167 (21), 165 (23), 155 (24), 153 (23).

2-Methyl-4'-(trifluoromethyl)-1,1'-biphenyl (14) ${ }^{49}$

Colourless oil; yield: 420 mg (89\%);

${ }^{1} \mathrm{H}$ NMR (300 MHz, $\left.\mathrm{CDCl}_{3}\right): \delta=2.26\left(\mathrm{~s}, \mathrm{CH}_{3}, 3 \mathrm{H}\right)$, 7.19-7.31 (m, 4×ArH, 4H), 7.44, 7.67 (2d, $J=7.9$, 8.0, $4 \times \mathrm{ArH}, 2 \mathrm{H}, 2 \mathrm{H})$. 
${ }^{13} \mathrm{C} \mathrm{NMR}\left(75 \mathrm{MHz}, \mathrm{CDCl}_{3}\right.$ ): $\delta=20.3,125.0,125.1$, 126.0, 127.9, 129.5, 130.5, 135.2, 140.5, 145.6.

MS (EI): $m / z=236\left(\mathrm{M}^{+}, 100 \%\right), 235$ (19), 217 (10), 167 (76), 166 (21).

1-[4'-(tert-Butyl)-1,1'-biphenyl-4-yl]ethanone (15)

White solid; yield: $500 \mathrm{mg}$ (99 \%); m.p. $=126-127^{\circ} \mathrm{C}$ (EtOAc).

${ }^{1} \mathrm{H}$ NMR (300 MHz, $\left.\mathrm{CDCl}_{3}\right): \delta=1.37\left[\mathrm{~s},\left(\mathrm{C}\left(\mathrm{CH}_{3}\right)_{3}\right.\right.$, $9 \mathrm{H}$ ], 2.63 (s, $\left.\mathrm{COCH}_{3}, 3 \mathrm{H}\right), 7.49,7.58,(2 \mathrm{~m}, 4 \times \mathrm{ArH}$, 2H, 2H), 7.68 (d, $J=5.1 \mathrm{~Hz}, 2 \times \mathrm{ArH}, 2 \mathrm{H}), 8.02$ (d, $J=$ $5.1 \mathrm{~Hz}, 2 \times \mathrm{ArH}, 2 \mathrm{H})$.

${ }^{13} \mathrm{C}$ NMR (75 MHz, $\mathrm{CDCl}_{3}$ ): $\delta=26.6,31.3,34.6$, 125.9, 126.9, 127.0, 128.9, 135.6, 136.9, 145.6, 151.4, 197.8.

MS (EI): $m / z=252\left(\mathrm{M}^{+}, 37 \%\right), 238$ (20), 237 (100), 209 (12), 97 (10).

\section{1-(4'-Hydroxy-1,1'-biphenyl-4-yl)ethanone (16)}

White solid; yield: 255 mg (60 \%); m.p. 204-205 ${ }^{\circ} \mathrm{C}$

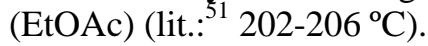

${ }^{1} \mathrm{H}$ NMR (300 MHz, $\left.\mathrm{CD}_{3} \mathrm{OD}\right): \delta=2.61\left(\mathrm{~s}, \mathrm{CH}_{3}, 3 \mathrm{H}\right)$, 6.88 (d, $J=8.7 \mathrm{~Hz}, 2 \times \mathrm{ArH}, 2 \mathrm{H}), 7.54$ (d, $J=8.7 \mathrm{~Hz}$, $2 \times \mathrm{ArH}, 2 \mathrm{H}), 7.69$ (d, $J=8.5 \mathrm{~Hz}, 2 \times \mathrm{ArH}, 2 \mathrm{H}), 8.02$ (d, $J=8.5 \mathrm{~Hz}, 2 \times \mathrm{ArH}, 2 \mathrm{H})$.

${ }^{13} \mathrm{C}$ NMR (75 MHz, $\left.\mathrm{CD}_{3} \mathrm{OD}\right): \delta=27.5,117.7,128.2$, 130.2, 131.0, 133.0, 137.0, 148.1, 160.1, 202.

MS (EI): $m / z=212\left(\mathrm{M}^{+}, 64 \%\right), 198$ (15), 197 (100), 169 (13), 141 (10), 139 (14).

\section{3-[4-(tert-Butyl)phenyl]pyridine (17) ${ }^{52}$}

White solid; yield: $177 \mathrm{mg}$ (42 \%); m.p. 62-63 ${ }^{\circ} \mathrm{C}$ (EtOAc) (lit.: ${ }^{52} 65-66^{\circ} \mathrm{C}$ ).

${ }^{1} \mathrm{H}$ NMR (300 MHz, $\left.\mathrm{CDCl}_{3}\right): \delta=1.36\left[\mathrm{~s},\left(\mathrm{C}\left(\mathrm{CH}_{3}\right)_{3}\right.\right.$, 9H], 7.33 (ddd, $J=0.7,4.8,7.9 \mathrm{~Hz}, \mathrm{ArH}, 1 \mathrm{H}), 7.51$ (m, $4 \times$ ArH, 4H), 7.86 (ddd, $J=1.7,2.3,7.9 \mathrm{~Hz}, \mathrm{ArH}$, $1 \mathrm{H}), 8.56$ (dd, $J=1.6,4.8 \mathrm{~Hz}, \mathrm{ArH}, 1 \mathrm{H}), 8.85$ (m, ArH, 1H).

${ }^{13} \mathrm{C} \mathrm{NMR}\left(75 \mathrm{MHz}, \mathrm{CDCl}_{3}\right): \delta=31.2,34.6,123.4$, 126.0, 126.7, 134.1, 134.8, 136.4, 148.1, 148.2, 151.2.

MS (EI): $m / z=211\left(\mathrm{M}^{+}, 31 \%\right), 197$ (16), 196 (100), 168 (25), 167 (11).

\section{(E)-1-(4-Styrylphenyl)ethanone (18)}

Colourless solid; yield: 408 mg (92 \%); m.p. 141-142 ${ }^{\circ} \mathrm{C}$ (EtOAc) (lit.: $\left.{ }^{53} 140-141^{\circ} \mathrm{C}\right)$.

${ }^{1} \mathrm{H}$ NMR (300 MHz, $\mathrm{CDCl}_{3}$ ): $\delta=2.61\left(\mathrm{~s}, \mathrm{CH}_{3}, 3 \mathrm{H}\right.$ ), 7.13 (d, $J=16.4 \mathrm{~Hz}, H \mathrm{C}=\mathrm{CH}, 1 \mathrm{H}), 7.23$ (d, $J=16.4$ $\mathrm{Hz}, \mathrm{HC}=\mathrm{CH}, 1 \mathrm{H}), 7.31,7.39,7.56(3 \mathrm{~m}, 7 \times \mathrm{ArH}, 1 \mathrm{H}$, 2H, 4H), 7.95 (d, $J=8.4 \mathrm{~Hz}, 2 \mathrm{H}, 2 \times \mathrm{ArH}, 2 \mathrm{H})$.

${ }^{13} \mathrm{C}$ NMR (75 MHz, $\mathrm{CDCl}_{3}$ ): $\delta=26.6,126.5,126.8$, 127.4, 128.3, 128.8, 128.9, 131.4, 135.9, 136.7, 142.0, 197.5.

MS (EI): $m / z=222\left(\mathrm{M}^{+}, 69 \%\right), 208$ (17), 207 (100), 179 (21), 178 (59), 152 (10).

(E)-4-(tert-Butyl)stilbene (19) ${ }^{54}$
White solid; yield: $322 \mathrm{mg}$ (68 \%); m.p. $95-96{ }^{\circ} \mathrm{C}$ (EtOAc) (lit.: $\left.{ }^{54} 96-98{ }^{\circ} \mathrm{C}\right)$.

${ }^{1} \mathrm{H}$ NMR (300 MHz, $\left.\mathrm{CDCl}_{3}\right): \delta=1.34\left[\mathrm{~s}, \mathrm{C}\left(\mathrm{CH}_{3}\right)_{3}\right.$, $9 \mathrm{H}$ ], $7.09(\mathrm{~m}, \mathrm{HC}=\mathrm{CH}, 2 \mathrm{H}), 7.25,7.37,7.49$ (3m, $9 \times \mathrm{ArH}, 1 \mathrm{H}, 4 \mathrm{H}, 4 \mathrm{H})$.

$\left.{ }^{13} \mathrm{C} \mathrm{NMR} \mathrm{(75} \mathrm{MHz,} \mathrm{CDCl}_{3}\right): \delta=31.2,34.6,125.6$, 126.2, 126.4, 127.4, 127.9, 128.5, 128.6, 134.6, 137.5, 150.8 .

MS (EI): $m / z=236\left(\mathrm{M}^{+}, 50 \%\right), 222$ (19), 221 (100), 178 (13).

Supporting Information for this article is available online at http://www.thiemeconnect.com/products/ejournals/journal/10.1055/s00000084. If Supporting Information is not being supplied for this manuscript, please delete this paragraph.

\section{Acknowledgment}

Financial support from the Ministerio de Ciencia e Innovación (MICINN) of Spain (Project Nos. CTQ2007-65218, CTQ201124165, Consolider Ingenio 2010 CSD2007-00006), the Generalitat Valenciana (PROMETEO/2009/039 and FEDER), and the Universidad de Alicante is acknowledged.

\section{References}

(1) Herrmann, W. A. Angew. Chem. Int. Ed. 2002, 41, 1290.

(2) (a) Crudden, C. M.; Allen, D. P. Coord. Chem. Rev. 2004, 248, 2247. (b) Kantchev, E. A. B.; O'Brien, C. J.; Organ, M. G. Angew. Chem. Int. Ed. 2007, 46, 2768. (c) Hahn, F. E.; Jahnke, M. C. Angew. Chem. Int. Ed. 2008, 47, 3122. (d) Marion, N.; Nolan, S. P. Acc. Chem. Res. 2008, 41, 1440. (e) Würtz, S.; Glorius, F. Acc. Chem. Res. 2008, 41, 1523. (f) Díez-González, S.; Marion, N.; Nolan, S. P. Chem. Rev. 2009, 109, 3612. (g) Lin, J. C. Y.; Huang, R. T. W.; Lee, C. S.; Bhattacharyya, A.; Hwang, W. S.; Lin, I. J. B. Chem. Rev. 2009, 109, 3561. (h) Samojłowicz, C.; Bieniek, M.; Grela, K. Chem. Rev. 2009, 109, 3708. (i) Nolan, S. P. Acc. Chem. Res. 2010, 44, 91. (j) Martin, D.; Melaimi, M.; Soleilhavoup, M.; Bertrand, G. Organometallics 2011, 30, 5304. (k) Fortman, G. C.; Nolan, S. P. Chem. Soc. Rev. 2011, 40, 5151. (l) Valente, C.; Çalimsiz, S.; Hoi, K. H.; Mallik, D.; Sayah, M.; Organ, M. G. Angew. Chem. Int. Ed. 2012, 51, 3314.

(3) (a) Hindi, K. M.; Panzner, M. J.; Tessier, C. A.; Cannon, C. L.; Youngs, W. J. Chem. Rev. 2009, 109, 3859. (b) Cisnetti, F.; Gautier, A. Angew. Chem. Int. Ed. 2013, 52, 11976.

(4) Mercs, L.; Albrecht, M. Chem. Soc. Rev. 2010, 39, 1903.

(5) Fèvre, M.; Pinaud, J.; Gnanou, Y.; Vignolle, J.; Taton, D. Chem. Soc. Rev. 2013, 42, 2142.

(6) (a) Brauer, D. J.; Kottsieper, K. W.; Liek, C.; Stelzer, O.; Waffenschmidt, H.; Wasserscheid, P. J. Organomet. Chem. 2001, 630, 177. (b) Yang, C.; Lee, H. M.; Nolan, S. P. Org. Lett. 2001, 3, 1511. (c) Bronger, R. P. J.; Silva, S. M.; Kamer, P. C. J.; van Leeuwen, P. W. N. M. Chem. Commun. 2002, 3044. (d) Lee, H. M.; Chiu, P. L.; Zeng, J. Y. Inorg. Chim. Acta 2004, 357, 4313.

(7) (a) Herrmann, W. A.; Köcher, C.; Gooßen, L. J.; Artus, G. R. J. Chem. Eur. J. 1996, 2, 1627. (b) Arnold, P. L.; Mungur, S. A.; Blake, A. J.; Wilson, C. Angew. Chem. Int. Ed. 2003, 42, 5981. (c) Bonnet, L. G.; Douthwaite, 
R. E.; Hodgson, R.; Houghton, J.; Kariuki, B. M.; Simonovic, S. Dalton Trans. 2004, 3528. (d) Spencer, L. P.; Winston, S.; Fryzuk, M. D. Organometallics 2004, 23, 3372.

(8) (a) Schwarz, J.; Böhm, V. P. W.; Gardiner, M. G.; Grosche, M.; Herrmann, W. A.; Hieringer, W.; Raudaschl-Sieber, G. Chem. Eur. J. 2000, 6, 1773. (b) Glas, H.; Herdtweck, E.; Spiegler, M.; Pleier, A.-K.; Thiel, W. R. J. Organomet. Chem. 2001, 626, 100. (c) Prühs, S.; Lehmann, C. W.; Fürstner, A. Organometallics 2004, 23, 280. (d) Zarka, M. T.; Bortenschlager, M.; Wurst, K.; Nuyken, O.; Weberskirch, R. Organometallics 2004, 23, 4817. (e) Melaiye, A.; Sun, Z.; Hindi, K.; Milsted, A.; Ely, D.; Reneker, D. H.; Tessier, C. A.; Youngs, W. J. J. Am. Chem. Soc. 2005, 127, 2285. (f) Arnold, P. L.; Sanford, M. S.; Pearson, S. M. J. Am. Chem. Soc. 2009, 131, 13912. (g) Benítez, M.; Mas-Marzá, E.; Mata, J. A.; Peris, E. Chem. Eur. J. 2011, 17, 10453. (h) Eguillor, B.; Esteruelas, M. A.; García-Raboso, J.; Oliván, M.; Oñate, E.; Pastor, I. M.; Peñafiel, I.; Yus, M. Organometallics 2011, 30, 1658. (i) Meyer, A.; Unger, Y.; Poethig, A.; Strassner, T. Organometallics 2011, 30, 2980. (j) Straubinger, C. S.; Jokić, N. B.; Högerl, M. P.; Herdtweck, E.; Herrmann, W. A.; Kühn, F. E. J. Organomet. Chem. 2011, 696, 687.

(9) Fei, Z.; Zhao, D.; Geldbach, T. J.; Scopelliti, R.; Dyson, P. J. Chem. Eur. J. 2004, 10, 4886.

(10) (a) Shi, M.; Qian, H.-X. Appl. Organometal. Chem. 2005, 19, 1083. (b) Ray, L.; Katiyar, V.; Raihan, M. J.; Nanavati, H.; Shaikh, M. M.; Ghosh, P. Eur. J. Inorg. Chem. 2006, 3724.

(11) Cole, A. C.; Jensen, J. L.; Ntai, I.; Tran, K. L. T.; Weaver, K. J.; Forbes, D. C.; Davis, J. H. J. Am. Chem. Soc. 2002, 124, 5962.

(12) Meyer, A.; Taige, M. A.; Strassner, T. J. Organomet. Chem. 2009, 694, 1861.

(13) (a) Kratochvil, B.; Ondracek, J.; Velisek, J.; Hasek, J. Acta Crystallogr. C 1988, 44, 1579. (b) Davídek, T.; Velísek, J.; Davídek, J.; Pech, P. J. Agric. Food Chem. 1991, 39, 1374.

(14) Kühl, O.; Palm, G. Tetrahedron: Asymmetry 2010, 21, 393.

(15) Velísek, J.; Davídek, T.; Davíek, J.; Trska, P.; Kvasnicka, F.; Velcová, K. J. Food Sci. 1989, 54, 1544.

(16) Chai, X.-C.; Sun, Y.-Q.; Lei, R.; Chen, Y.-P.; Zhang, S.; Cao, Y.-N.; Zhang, H.-H. Cryst. Growth Des. 2009, 10, 658.

(17) Fei, Z.; Geldbach, T. J.; Scopelliti, R.; Dyson, P. J. Inorg. Chem. 2006, 45, 6331.

(18) Wang, X.; Li, X.-B.; Yan, R.-H.; Wang, Y.-Q.; Gao, E.Q. Dalton Trans. 2013, 42, 10000.

(19) (a) Fei, Z.; Zhao, D.; Geldbach, T. J.; Scopelliti, R.; Dyson, P. J.; Antonijevic, S.; Bodenhausen, G. Angew. Chem. Int. Ed. 2005, 44, 5720. (b) Fei, Z.; Ang, W. H.; Geldbach, T. J.; Scopelliti, R.; Dyson, P. J. Chem. Eur. J. 2006, 12, 4014.

(20) Ma, C.; Li, J.; Peng, J.; Bai, Y.; Zhang, G.; Xiao, W.; Lai, G. J. Organomet. Chem. 2013, 727, 28.

(21) (a) Alonso, D. A.; Najera, C. In Science of Synthesis: Water in Organic Synthesis; Kobayashi, S., Ed.; Georg Thieme Verlag: Stuttgart, 2012. (b) Deng, C.-L.; Guo, S.-M.; Xie, Y.-X.; Li, J.-H. Eur. J. Org. Chem. 2007, 1457. (c) Mao, S.-L.; Sun, Y.; Yu, G.-A.; Zhao, C.; Han, Z.-J.; Yuan, J.; Zhu, X.; Yang, Q.; Liu, S.-H. Org. Biomol. Chem. 2012, 10, 9410. (d) Liu, C.; Zhang, Y.; Liu, N.; Qiu, J. Green Chem. 2012, 14, 2999. (e) Mondal, M.; Bora, U. Green Chem. 2012, 14, 1873. (f) Zhou, P.; Wang, H.; Yang, J.; Tang, J.; Sun, D.; Tang, W.
RSC Adv. 2012, 2, 1759. (g) Liu, C.; Rao, X.; Zhang, Y.; Li, X.; Qiu, J.; Jin, Z. Eur. J. Org. Chem. 2013, 4345. (h) Dewan, A.; Bora, U.; Borah, G. Tetrahedron Lett. 2014, 55, 1689. (i) Mondal, M.; Bora, U. Tetrahedron Lett. 2014, 55, 3038. (j) Liu, L.; Dong, Y.; Tang, N. Green Chem. 2014, 16, 2185.

(22) Lipshutz, B. H.; Petersen, T. B.; Abela, A. R. Org. Lett. 2008, 10, 1333.

(23) (a) Fleckenstein, C.; Roy, S.; Leuthäuber, S.; Plenio, H. Chem. Commun. 2007, 2870. (b) Roy, S.; Plenio, H. Adv. Synth. Catal. 2010, 352, 1014. (c) Godoy, F.; Segarra, C.; Poyatos, M.; Peris, E. Organometallics 2011, 30, 684.

(24) For palladium PEPPSI (Pyridine Enhanced Precatalysts Preparation, Stabilization and Initiation) complexes, see: (a) Valente, C.; Çalimsiz, S.; Hoi, K. H.; Mallik, D.; Sayah, M.; Organ, M. G. Angew. Chem. Int. Ed. 2012, 51, 3314. (b) Benhamou, L.; Besnard, C.; Kündig, E. P. Organometallics 2013, 33, 260. (c) Hoi, K. H.; Coggan, J. A.; Organ, M. G. Chem. Eur. J. 2013, 19, 843. (d) Valente, C.; Pompeo, M.; Sayah, M.; Organ, M. G. Org. Process Res. Dev. 2013, 18, 180.

(25) Türkmen, H.; Can, R.; Çetinkaya, B. Dalton Trans. 2009, 7039.

(26) Liu, N.; Liu, C., Jin, Z. Green Chem. 2012, 14, 592.

(27) (a) Peñafiel, I.; Pastor, I. M.; Yus, M.; Esteruelas, M. A.; Oliván, M.; Oñate, E. Eur. J. Org. Chem. 2011, 7174. (b) Peñafiel, I.; Pastor, I. M.; Yus, M. Eur. J. Org. Chem. 2012, 3151. (c) Peñafiel, I.; Pastor, I. M.; Yus, M. Eur. J. Org. Chem. 2013, 1479.

(28) Peñafiel, I.; Pastor, I. M.; Yus, M.; Esteruelas, M. A.; Oliván, M. Organometallics 2012, 31, 6154.

(29) Amatore, C.; Le Duc, G.; Jutand, A. Chem. Eur. J. 2013, 19, 10082.

(30) Nishikata, T.; Lipshutz, B. H. J. Am. Chem. Soc. 2009, 131, 12103.

(31) Lipshutz, B. H.; Abela, A. R. Org. Lett. 2008, 10, 5329.

(32) A design of experiments approach was considered for the first optimization process: (a) Chen, J. J.; Nugent, T. C.; Lu, C. V.; Kondapally, S.; Giannousis, P.; Wang, Y.; Wilmot, J. T. Org. Process Res. Dev. 2003, 7, 313. (b) Aggarwal, V. K.; Staubitz, A. C.; Owen, M. Org. Process Res. Dev. 2006, 10, 64. (c) Veum, L.; Pereira, S. R. M.; van der Waal, J. C.; Hanefeld, U. Eur. J. Org. Chem. 2006, 1664. (d) Denmark, S. E.; Butler, C. R. J. Am. Chem. Soc. 2008, 130, 3690. (e) Kuethe, J. T.; Tellers, D. M.; Weissman, S. A.; Yasuda, N. Org. Process Res. Dev. 2009, 13, 471. (f) Mendiola, J.; García-Cerrada, S.; de Frutos, Ó.; de la Puente, M. L.; Gu, R. L.; Khau, V. V. Org. Process Res. Dev. 2009, 13 292. (g) Massari, L.; Panelli, L.; Hughes, M.; Stazi, F.; Maton, W.; Westerduin, P.; Scaravelli, F.; Bacchi, S. Org. Process Res. Dev. 2010, 14, 1364. (h) Mateos, C.; Mendiola, J.; Carpintero, M.; Mínguez, J. M. Org. Lett. 2010, 12, 4924. (i) Mathiessen, B.; Jensen, A. T. I.; Zhuravlev, F. Chem. Eur. J. 2011, 17, 7796. (j) Nishimura, K.; Kinugawa, M. Org. Process Res. Dev. 2012, 16, 225.

(33) For further details, see the Supporting Information.

(34) (a) Molander, G. A.; Ellis, N. Acc. Chem. Res. 2007, 40, 275. (b) Molander, G. A.; Canturk, B. Angew. Chem. Int. Ed. 2009, 48, 9240.

(35) Butters, M.; Harvey, J. N.; Jover, J.; Lennox, A. J. J.; Lloyd-Jones, G. C.; Murray, P. M. Angew. Chem. Int. Ed. 2010, 49, 5156.

(36) During the optimization reaction, it was pointed out that the reaction without ligand gave lower yields (see Figure 1c and Supplementary Material). In any case, under the optimal conditions described in Table 2 (for 
both type of boron reagents), in the absence of $\mathbf{1}$, the product 2 was obtained with a yield lower than $70 \%$ for the same reaction time.

(37) (a) Molander, G. A.; Biolatto, B. Org. Lett. 2002, 4, 1867. (b) Molander, G. A.; Biolatto, B. J. Org. Chem. 2003, 68, 4302.

(38) (a) Foley, P.; DiCosimo, R.; Whitesides, G. M. J. Am. Chem. Soc. 1980, 102, 6713. (b) Whitesides, G. M., Hackett, M.; Brainard, R. L.; Lavalleye, J. P. P. M.; Sowinski, A. F.; Izumi, A. N.; Moore, S. S.; Brown, D. W.; Staudt, E. M. Organometallics 1985, 4, 1819. (c) Widegren, J. A.; Bennett, M. A.; Finke, R. G. J. Am. Chem. Soc. 2003, 125, 10301. (d) Widegren, J. A.;

Finke, R. G. J. Molec. Catal. A Chem. 2003, 198, 317.

(39) (a) Alonso, D. A.; Cívicos, J. F.; Nájera, C. Synlett 2009, 3011. (b) Desmartes, C.; Omar-Amrani, R.; Walcarius, A.; Lambert, J.; Champagne, B.; Fort, Y.; Schneider, R. Tetrahedron 2008, 64, 372.

(40) (a) Alacid, E.; Nájera, C. Org. Lett. 2008, 10, 5011. (b) Commercially available (Sigma-Aldrich).

(41) Grosse, A. V.; Mavity, J. M.; Ipatieff, V. N. J. Org. Chem. 1938, 3, 448.

(42) Kuriyama, M.; Shimazawa, R.; Shirai, R. Tetrahedron 2007, 63, 9393.

(43) Molander, G. A.; Iannazzo, L. J. Org. Chem. 2011, 76, 9182.

(44) Cho, C.-H.; Sun, M.; Seo, Y.-S.; Kim, C.-B.; Park, K. J. Org. Chem. 2005, 70, 1482.

(45) Lee, H. W.; Lam, F. L.; So, C. M.; Lau, C. P.; Chan, A. S. C.; Kwong, F. Y. Angew. Chem. Int. Ed. 2009, 48, 7436.

(46) Bernini, R.; Cacchi, S.; Fabrizi, G.; Forte, G.; Petrucci, F.; Prastaro, A.; Niembro, S.; Shafir, A.; Vallribera, A. Green Chem. 2010, 12, 150.

(47) Walker, S. D.; Barder, T. E.; Martinelli, J. R.; Buchwald, S. L. Angew. Chem. Int. Ed. 2004, 43, 1871.

(48) Ackermann, L.; Gschrei, C. J.; Althammer, A.; Riederer, M. Chem. Commun. 2006, 1419.

(49) Song, C.; Ma, Y.; Chai, Q.; Ma, C.; Jiang, W.; Andrus, M. B. Tetrahedron 2005, 61, 7438.

(50) Zhang, Y.; Shi, H.; Ke, Y.; Cao, Y. J. Lumin. 2007, 124, 51.

(51) Allan, G. M.; Vicker, N.; Lawrence, H. R.; Tutill, H. J.; Day, J. M.; Huchet, M.; Ferrandis, E.; Reed, M. J.; Purohit, A.; Potter, B. V. L. Bioorg. Med. Chem. 2008, 16, 4438.

(52) Kobayashi, O.; Uraguchi, D.; Yamakawa, T. Org. Lett. 2009, 11, 2679.

(53) Solodenko, W.; Mennecke, K.; Vogt, C.; Gruhl, S.; Kirschning, A. Synthesis 2006, 1873.

(54) Masllorens, J.; Moreno-Mañas, M.; Pla-Quintana, A.; Roglans, A. Org. Lett. 2003, 5, 1559. 
